\title{
An Exploration into the Successful Development of the Leather-Shoe Industry in Ethiopia*
}

\author{
Tetsushi Sonobe, John E. Akoten and Keijiro Otsuka
}

\begin{abstract}
The leather-shoe industry in Ethiopia is thriving, and in the early 2000s, it managed to recover the domestic market which had once been swept by imported Chinese shoes. Using primary enterprise-level data, this paper finds that the industry has been growing not only because of a number of new entrants but also because of the growth of enterprises that have been improving product quality and developing new marketing systems. Such multifaceted improvements have been introduced by highly educated entrepreneurs, who have successfully expanded the size of their enterprises. This development pattern is similar to that commonly found in East Asia.
\end{abstract}

*Sonobe: Foundation for Advanced Studies on International Development, 7-22-1 Roppongi, Minato-ku, Tokyo 106-8677, Japan, Phone+81-3-6439-6211, Fax +81-3-6439-6010, email: sonobete@grips.ac.jp. Akoten: Institute of Policy Analysis and Research, Nairobi, Kenya, Norfolk Towers, Block F, 2nd Floor, Kijabe Road/Harry Thuku Road Junction, Nairobi, Kenya, Phone+254-0-20-2251179/2229128, Fax +254-0-20-2251162, email: akoten@ipar.or.ke/akotenjet@yahoo.com. Otsuka: Foundation for Advanced Studies on International Development, 7-22-1 Roppongi, Minato-ku, Tokyo 106-8677, Japan, Phone+81-3-6439-6228, Fax+81-3-6439-6010, email: otsuka@grips.ac.jp. We would like to acknowledge that this project was supported by the Global Center of Excellence Program of the National Graduate Institute of Policy Studies granted by the Ministry of Education and Science of the Japanese government._

JEL Classification Numbers: L67, O31 


\section{Introduction}

Manufacturing industries in Sub-Saharan Africa have generally been stagnant or shrinking for the last three decades (Bigsten and Söderbom, 2006). As Collier and Gunning (1999) and Fafchamps (2004) and many others argue, industrial development in Africa has been hindered by a myriad of problems ranging from high transportation costs, high transaction costs due to imperfect information, and imperfect contract enforcement to highly risky business and political environments. Moreover, both the provision of public services and the development of grass-roots institutions and social capital are considered to be insufficient in Africa to cope with such problems.

The World Bank and other organizations have collected large sets of enterprise data from many industries in various African countries in the 1990s. Using these data, a number of empirical analyses have been carried out to provide insights into the major constraints on industrial development. ${ }^{1}$ Few attempts, however, have been made to learn from prosperous industries, presumably because of the lack of successful cases of industrial development in Sub-Saharan Africa (McCormick, 1999). According to Bigsten and Söderbom (2006, p. 242) and Gunning and Mengistae (2001, p. 50), however, some African firms "have performed extremely well" and "African manufacturing firms are highly profitable."

This paper presents the results of our case study of successful industrial development based on field surveys conducted in one of the most labor-intensive industries in one of the poorest countries, i.e., the leather-shoe industry in Addis Ababa, Ethiopia. ${ }^{2}$ We collected primary data on the performance and characteristics of 90 private enterprises and two 
state-owned enterprises (SOEs) in this industry. It is widely believed by those who are engaged in this industry that 1000 or more factories are producing leather shoes in Addis Ababa. Most of them employ only ten workers or less, but several factories have hundreds of workers. In the early 2000s, China-made leather shoes flooded into the Ethiopian market plunging the local industry into a slump. Remarkably, however, the industry soon resumed vigorous growth not only taking the market back but even finding its way into the international market. While the majority of Ethiopian factory sell their product to domestic markets, some are exporting shoes in bulk to Italy and other developed countries as well as neighboring African countries. These high-performing enterprises are not SOEs but private enterprises. They are building or planning to build new large factories to start mass production of high-quality leather shoes for foreign markets.

The leather-shoe industry in Addis Ababa is exceptionally successful in Africa. We believe that this is a case worth investigating since it is expected to provide insight into the key to successful industrial development. A major finding is that the growth of this industry was driven initially by the massive entry of new enterprises established by former employees of the existing shoe factories but more recently by the growth in enterprise sizes due to improvements in the quality of products, marketing, and management. Such improvements were first made by highly educated entrepreneurs and subsequently followed by other enterprises. While the followers have grown in size, the leading enterprises have grown faster. Such a development pattern appears similar to the experience of successful cluster-based industrial development in China, Taiwan, and Japan, as is recently reported by Sonobe and Otsuka (2006a). 
The rest of the paper is organized as follows. Section 2 reviews the empirical literature on cluster-based industrial development in East Asia in comparison with the Ethiopian case and postulates several testable hypotheses. Section 3 describes our data collection method and the basic statistics concerning enterprise size, the educational and occupational backgrounds of owners, marketing and procurement, and enterprise growth. The results of the regression analyses are presented in Section 4 , followed by the summary of the findings and policy implications of the paper in Section 5.

\section{Comparative Perspective}

The production of leather shoes in Ethiopia dates from the late 1930s when Armenian merchants founded two shoe factories in Addis Ababa. ${ }^{3}$ These factories nurtured a number of shoemakers, who opened their own factories in Addis Ababa and trained their workers. Today, the neighborhood of Merkato, a huge marketplace in the city, swarms with shoemakers, wholesale shops dealing in leather, soles, and shoe accessories, and shoe retail stores.

Industrial clusters like this are ubiquitous in developing as well as developed countries because of the benefits of agglomeration economies originally pointed out by Marshall (1920). ${ }^{4}$ If transacting parties are located near each other, transport costs are saved, transaction costs due to imperfect information and imperfect contract enforcement are lowered, and good products and superior production practices diffuse quickly. Thus, industrial clusters enhance the division and specialization of labor among enterprises, the development of the market for skilled workers, and the dissemination of technical and 
managerial knowledge. Such agglomeration economies attract new enterprises to a cluster, making the cluster larger and reinforcing the agglomeration economies.

It is believed that more than 1000 enterprises are producing leather shoes in Addis Ababa. This cluster is as large as successful shoe clusters in other countries, e.g., Agra in India (Knorringa, 1999), the Sinos Valley in Brazil (Schmitz, 1995; Bazan and Navas-Aleman, 2004), and Leon and Guadalajara in Mexico (Rabelloti, 1995). Yet, as in East Asia and elsewhere (Sonobe and Otsuka, 2006a), the number of enterprises in the Ethiopian shoe industry grew rapidly in the early stage of industrial development due to spin-offs, i.e., the establishment of new enterprises by workers who had formerly worked for pioneering enterprises and who copied their production methods. Many industries in developing countries, however, ceased to grow after they had expanded in terms of the number of enterprises, e.g., the garment cluster in Nairobi (Akoten, et al., 2006). An industry ceases to grow when the profitability of producing low-quality products falls as their market supply increases relative to market demand. This is typically the case if the increase in market supply is not accompanied by improvements in product quality. By contrast, those clusters where product quality was successfully improved have continued to grow, as clearly indicated by the case studies conducted by Sonobe and Otsuka (2006a) in East Asia and Schmitz and Nadvi's (1999) compilation of case studies conducted in Latin America and South Asia.

According to the emerging literature on cluster-based industrial development in East Asia, quality improvement is accompanied by the introduction of new marketing methods and new production organizations (e.g., Sonobe et al., 2002, 2004, 2006a, 2006b). For 
example, the improvement of product quality is followed by branding and advertisement since profits increase only after the improved quality is correctly perceived by potential buyers. The operation of own retail shops and the employment of sales agencies are useful in protecting brand names of differentiated products. The production of high-quality and differentiated products requires the use of high-quality and specially designed parts. The establishment of a brand name and own marketing and procurement systems generates positive size effects, making a larger scale operation advantageous and, thus, large enterprises emerge in the quality improvement phase. ${ }^{5}$ Thus, the case studies of cluster-based industrial development commonly indicate that the further development of an industry after cluster formation is made possible by multifaceted innovations (or improvements) in technology, marketing, and organization. ${ }^{6}$

In view of the vital role played by multifaceted innovations in industrial development, questions arise as to what types of entrepreneurs carry them out and what characterizes early and late imitators. In all the eight case studies conducted by Sonobe and Otuska (2006a) in East Asia, the general human capital or formal education of entrepreneurs assumed greater importance in carrying out multifaceted innovations, even though there is no denying that the industry- and job-specific human capital acquired through experience is also important.

To investigate how similar the development pattern of the leather-shoe industry in Ethiopia is to the East Asian experience, we advance the following hypotheses based on the above review of the literature on cluster-based industrial development in East Asia: 
Hypothesis 1: Leading enterprises operated by highly educated and experienced entrepreneurs produce high-quality products and market them through own distribution systems designed to reach customers directly.

Hypothesis 2: To produce high-quality differentiated products, such leading enterprises purchase high-quality inputs directly from producers.

Hypothesis 3: To take advantage of improved product quality, established brand names, and direct marketing and procurement systems, the leading enterprises operate on a larger scale than others.

\section{Descriptive Analysis}

Sampling

In early January 2005, we began conducting informal interviews with the shoemakers who were members of the Ethiopian Tanners, Footwear, and Leather Garments Manufacturing Association. After several interviews, we decided to conduct a formal survey of enterprises and began considering about the sampling method. We visited the Central Statistics Authority and found that they did not have much information on leather-shoe producers. They recommended that we visit the association for information, but the association had only the 14 largest shoemakers as members and knew little about non-members, i.e. the vast majority of the shoe enterprises. Thus, we began visiting micro and small factories on back alleys behind the large marketplace named Merkato. Since these factories were trying to escape detection by the government authorities, including the statistical office, it was impossible for us to find them without being guided by a 
knowledgeable person. We were able to become acquainted with two such persons and to hire them as guides. Since each guide knew the whereabouts of only a limited number of shoemakers, making a comprehensive list of shoemakers even within a small part of the cluster would require an unrealistically large number of guides. Instead, we requested several shoe store owners and our guides to write down all the names of the shoemakers that they knew, whether large or small, and then selected 100 enterprises randomly. Very new enterprises founded in 2003 or later are not included in the sample, partly because our guides were not familiar with such new enterprises, and partly because we were interested in the analysis of enterprise growth, in which the data on very new enterprises could not be used. We conducted a survey in February and early March 2005 and obtained reliable data from 90 private enterprises.

In addition, we interviewed the managers of two SOEs, Tikure Abbay and Anbessa, the oldest shoe factories founded by Armenians in the late 1930s. They were nationalized by the military government in 1974 and remained the largest and second largest shoemakers in the country. In recent years, private enterprises had caught up with these SOEs and, thus, the latter were under the process of privatization. ${ }^{7}$ Although we obtained reliable data from these two SOEs, our analysis below focuses on the private enterprises because they were so different in behaviors.

\section{Entrepreneur Cohorts and Enterprise Sizes}

Some entrepreneurs in the sample are second-generation shoe entrepreneurs in the sense that their parents were shoe factory owners, shoe workers, or shoe traders. In Table 1 as well as the other descriptive tables, the 90 private enterprises in the sample are classified 
into six types according to whether the owner was first-generation or second-generation and the years of operation by the current head of the enterprise. As column 4 of Table 1 shows, 18 sample enterprises were run by second-generation entrepreneurs. The oldest private enterprise in the sample is OK Jamaica, which was founded in 1969 by a former shoe factory worker and succeeded by his son in 1985. Other two private enterprises in the sample were founded by the current owners' parents. The rest, i.e., 15 second-generation entrepreneurs, did not succeed businesses from their parents, but their parents had engaged in shoe manufacturing or trading.

\section{"INSERT Table 1 Here."}

As shown in column 1 of Table 1, 47 sample enterprises were founded in 2001 or 2002. According to our respondents, the worst year for the industry was 2001 when the market was flooded with Chinese shoes, and the industry was still in poor shape in 2002. Figure 1 shows the changes in imports and exports of leather shoes and their average prices (c.i.f. price in the case of imports and f.o.b. price in the case of exports) from 1997 to 2006. ${ }^{8}$ Since it is known that most, if not all, imported leather shoes came from China, it is clear that the China shock took place primarily in 2001. The imports, however, sharply declined thereafter. According to our interviews, this can be explained partly by the fact that although Chinese shoes that came to Ethiopia had better finishing and were more fashionable, consumers quickly learned that they were much less durable and, hence, began to prefer locally produced shoes. The low quality of imported products would be reflected in their low average price, which was much lower than the average price of the shoes exported from Ethiopia. Moreover, the quality of domestically produced shoes was 
improved, which would have culminated in the recent surge of exports of the Ethiopian shoes. It must also be pointed out that the remaining imports from China are primarily women's footwear, of which durability is not the most important trait. The focus of this study as well as the almost all sample enterprises is on the production of men's leather shoes.

"INSERT Figure 1 Here."

Since the shoe manufacturing is highly labor-intensive, the international competitiveness of this industry is determined importantly by wage rate. Table 2 compares the average annual nominal wage earnings of workers in the urban leather industry in China with those of the leather-shoe industry in Ethiopia based on our own survey data, both expressed in the U.S. dollars by using the respective official exchange rates. $^{9}$ It is clear that the wage rate in Ethiopia is very low and less than one-half in China, which suggests that potentially Ethiopia has a comparative advantage in the shoe industry vis-à-vis China, to the extent that its production technology and management efficiency are not significantly inferior. This low wage rate in Ethiopia would also explain, at least partly, why imports of leather shoes from China declined.

\section{"INSERT Table 2 Here."}

Despite the China shock, the entry of new enterprises was very active in 2001 and 2002. The fact that the majority of the enterprises were new also indicates that only a small number of enterprises could survive in the face of intense market competition. Our guides were good examples: they had had their own businesses, which ended in failure recently, and they had become shoe workers employed on a piece-rate wage basis. Thus, 
both new entry and factory closure were of frequent occurrence. These observations are consistent with Gunning and Mengitae's (2001) argument that the process of market selection was as strong in Africa as anywhere else in the 1990s.

Table 1 also presents the average size in terms of the number of workers and value added in 2004. ${ }^{10}$ Clearly, enterprise size tended to increase with the years of operation by the current entrepreneur, for which respondents provided two explanations. Firstly, the size of production is constrained by the size of working capital, especially cash for the purchase of leather and other materials. As an entrepreneur accumulates working capital, he can increase the size of his enterprise. Secondly, enterprise size also depends on the competence of the entrepreneur for managing personnel, designing shoes, costing, marketing, and so on, which is gained through learning by doing, including both the own development of useful ideas and imitation.

As shown in Table 1, the enterprises of the second-generation entrepreneurs tended to be larger given the years of their operation. Their advantage over the first-generation entrepreneurs would arise from diverse sources, such as inherited talents, the home environment in which they were raised, and advice and financial support provided by parents. As mentioned earlier, only three second-generation entrepreneurs in the sample inherited enterprises from their parents. Moreover, one of these three enterprises was smaller than the average of all the sample enterprises in 2004. Thus, the large part of the advantage of the second-generation shoe entrepreneurs is likely to come from channels other than the inheritance of the parent's business itself.

\section{Characteristics of Entrepreneurs}


Almost all the parents of those entrepreneurs born outside Addis Ababa were farmers, whereas the parents of those entrepreneurs born in Addis Ababa were shoemakers, traders dealing in shoes, grains, and textiles, tailors, carpenters, mechanics, and a soldier. ${ }^{11}$ In the parents' era, new shoemakers were young dwellers in Addis Ababa. Later on, young men and women also came from the provinces to become shoemakers. The parents of the second-generation entrepreneurs tended to have some education because most of them were raised in Addis Ababa. By contrast, a majority of the parents of the first-generation entrepreneurs were farmers and had no education.

Of the 52 entrepreneurs born outside Addis Ababa, 45 were born in Butajira, which is located about $170 \mathrm{~km}$ south of Addis Ababa and is the heartland of Gurage, one of more than 80 ethnic groups in Ethiopia. Gurage people account for about two percent of the total population but are said to play disproportionately active parts in the business world. In Mengistae's (2001) sample which covers registered businesses in various industries in Addis Ababa, a third of the manufacturing enterprises are owned by Gurage entrepreneurs. In Lika's (1997) sample of shoemakers, two thirds are Gurage. ${ }^{12}$ In our sample, the presence of Gurage entrepreneurs is even stronger: they account for 86 percent in the full sample and 82 percent in the sub-sample of entrepreneurs born in Addis Ababa. The firstand second-generation entrepreneurs were similar in terms of ethnicity and the number of family members and relatives working in the leather-shoe industry.

On average, the first-generation entrepreneurs had only 8.5 years of schooling, whereas the second-generation entrepreneurs had 11.8 years. The difference is statistically significant at 1 percent level. During the survey, we obtained the impression that 
entrepreneurs tended to consider themselves highly educated if they had entered a university. If we apply this criterion, the first- and second-generation entrepreneurs appear even more different, as shown in the fifth and eleventh rows in Table 1. Interestingly, the percentage of the second-generation entrepreneurs who entered a university increased with the years of operation. This observation suggests that high education increased the likelihood of enterprise survival, even though it seems difficult to establish the causality. The fact that highly educated sons chose to work in the shoe industry instead of going to the public and other sectors suggests that the shoe business had been expected to be profitable. ${ }^{13}$ The majority of them majored in accounting.

The occupational backgrounds of the entrepreneurs were homogenous. All but six of them were spin-offs, who had worked at shoe factories before becoming entrepreneurs. Of the six exceptions, two were former shoe traders, who were second-generation, and four came from other industries. The first- and second-generation entrepreneurs differ, however, in the years of prior experience in this industry. While the first-generation entrepreneurs had spent 10 years on average on acquiring skills and accumulating funds before starting up their own businesses, the second-generation entrepreneurs had spent only five years in preparation (see the sixth and twelfth rows in Table 1).

\section{Quality Improvement}

Because shoes were mainly handcrafted at micro and small factories, new entry required the purchase of only a small amount of leather and other materials for use in the first few weeks, and thus there was little sunk cost. As a result, the massive entry of new enterprises occurred every year. As mentioned earlier, however, many entrants exited the 
industry soon, even though accurate statistical data on exit are unavailable. According to a knowledgeable respondent, the key to the survival and growth of a new entrant is to establish a good reputation for producing durable and attractive shoes with good leather, and by doing so, the currently large enterprises have grown large. This view seems to be shared widely in the shoe industry in Addis Ababa, as all the respondents agreed on the importance of product quality and reputation.

Table 3 shows the average factory price of men's leather shoes as a proxy for product quality. ${ }^{14}$ Consistent with Hypothesis 1 , the average price tended to be higher for those enterprises operated by experienced, second-generation entrepreneurs. The highest average price in 2004 was $\$ 17.34$ recorded by OK Jamaica, the oldest and the fifth largest enterprise in our sample. Relatively new enterprises did not produce expensive shoes, partly because they could not afford to procure expensive leather, and partly because they had neither good marketing channels suitable to high-quality shoes nor the ability to develop attractive designs yet. Thus, there was a wide spectrum of shoe prices even though the importance of product quality was recognized by every shoemaker. ${ }^{15}$

"INSERT Table 3 Here.”

Table 3 presents the data on marketing channels in 2004 as well. New enterprises were totally dependent on retail shops in Addis Ababa, wholesalers who hawk shoes in the provinces, and their agents for marketing. They did not have any other marketing channels such as own retail shops, exports, and special orders of working shoes from the government and large companies. Consistent with Hypothesis 1, long-established enterprises, especially those operated by second-generation entrepreneurs, tended to 
develop some such channels to directly reach the ultimate customers. The table also indicates that the fraction of sales revenues from such direct marketing was positively correlated with the average price and that the experienced, second-generation entrepreneurs increased this fraction.

Export was negligible in 2004 in the sample as a whole, but it accounted for 25 percent of the sales at Ramsey and 5 percent at three enterprises including OK Jamaica. Ramsey was the fourth largest private enterprise in the sample in 2004 and exported military shoes to neighboring countries. OK Jamaica was exporting high-quality men's shoes mainly to South Africa, Botswana, and Israel. To increase exports, both enterprises were building large factories in an industrial park newly developed by the government. In this industrial park, about eight other large shoemakers were building or planning new factories. Among them was Peacock, the third largest private enterprise in 2000 and the largest in 2004 in our sample. Its new factory had commenced operation just before we visited it in January 2005, and it had just shipped the first batch of OEM (own equipment manufacturing) exports to an Italian company, under the guidance of a few Italian technicians dispatched by that company. After our survey, we revisited this factory twice. In June 2005, the entrepreneur said that its production doubled in a half year with the same work force and machines. In February 2006, he said that its export business had been growing fast. Such development is consistent with the export data shown in Figure 1.

Table 3 also presents the data on material procurement, which are available only for 2004. Whether large or small, most shoemakers in Addis Ababa purchase leather, soles, and accessories. Large and small enterprises, however, differed in procurement sources. 
Consistent with Hypothesis 2, large enterprises purchased leather and soles in bulk directly from tanneries and factories or from abroad, whereas small enterprises procured materials completely from material wholesalers in the marketplace. Bulk purchases were associated with volume discounts and hence cost-effective.

In Table 3, imported Chinese soles used by the producers of low-price shoes are not treated as imports because they were bought in the marketplace. What the table treats as imported soles are high-quality soles imported from Italy, Spain, and some other European countries. Beginning by importing soles, these shoemakers gradually developed connections with European enterprises and obtained information on advanced technology and the latest fashions from them. Another trend clearly seen among the largest enterprises was to establish own factories to produce rubber soles using molds imported from Taiwan or China. As of 2004, three sample enterprises and some other large shoemakers owned sole factories.

Thus, old enterprises run by second-generation entrepreneurs improved product quality by using expensive leather and soles, increased direct transactions with customers, and reduced procurement costs by purchasing materials directly from factories. In addition, they went to the United States and Europe as well as the neighboring countries to visit factories, shoe stores, and trade fairs. The leaders of the industry made a variety of observations abroad, which led them to adopt different business models. In fact, the second-generation entrepreneurs with more than ten years of operation visited European countries twice a year in the last five years, while others never $\mathrm{did}^{16}$. While some found it profitable to specialize in unfashionable products, such as military boots, some others 
attached importance to learning from Europe through OEM export. While some were eager to mechanize production processes, one entrepreneur was determined to develop the flexible division of labor among a large number of shoemakers by taking full advantage of the fact that they are clustered, which is reminiscent of flexible specialization developed in central and northwestern Italy, as described by Piore and Sabel (1984).

With these active leaders, the private sector of the industry achieved strong recovery from the China shock. The numbers in parentheses in Table 1 shows the average annual growth rates of the US dollar equivalent of value added by the type of entrepreneur. The China shock hit the enterprises operated by the experienced, second-generation entrepreneurs most seriously, but even they could record positive growth in value added in the latter two years under study. Many other enterprises that survived the market competition maintained positive growth even in the middle of the China shock and achieved fast growth in more recent years. The average annual growth rate of the sample enterprises was 10 percent from 2000 to 2002 and 25 percent from 2002 to $2004 .{ }^{17}$

\section{Regressions}

\section{Specification}

To test Hypotheses 1 to 3 advanced in Section 2, we examine the determinants of five dependent variables: (i) the price of men's shoes, (ii) the fraction of sales revenue from direct marketing, (iii) the fraction of the amount of leather that was directly procured from tanneries, (iv) that of soles directly procured from sole factories, and (v) enterprise size in

terms of value added. We also estimate a function that explains the determinants of 
enterprise growth, following the lead of the existing studies of enterprise growth in Africa. According to Hypotheses 1 and 2, the enterprises with highly educated and experienced entrepreneurs tend to produce more expensive shoes, and have greater proportions of direct marketing and direct procurement of materials. Hypothesis 3 predicts that these enterprises tend to be larger in production size. To capture the effects of high education, we use a dummy variable, called university dummy, which is equal to 1 if the entrepreneur was admitted to a university and 0 otherwise. To capture the effects of management experience, we use the years of operation by the current entrepreneur.

To test Hypotheses 1 and 2, we regress the dependent variables (i) to (iv) on the university dummy and the years of operation as well as other exogenous variables. Of the four dependent variables, shoe prices and marketing are available for 2000, 2002, and 2004. Hence, these dependent variables may be denoted $Y_{i t}$ with subscripts $i$ and $t$ indicating enterprises and years, respectively. The data on the direct procurement of materials are available only for 2004. The explanatory variables, which characterize enterprises, are all time-invariant, and the vector of these variables is denoted by $X_{i}$ without subscript $t$. The coefficients of $X_{i}$ may change over time. Thus, the regression equations we estimate is of the following form:

$$
Y_{i t}=X_{i} \alpha_{t}+e_{i t}
$$

where $\alpha_{t}$ is a vector of parameters to be estimated and $e_{i t}$ is an error term. Since all the explanatory variables are time-invariant, panel data models (i.e., fixed- and random-effects models) are not worth considering here. The shoe price equation is estimated with OLS, but the functions explaining the direct marketing proportion and the proportion of the direct 
procurement of leather are estimated with the two-limit Tobit estimator because the data on these variables are censored at 0 and 1. The model for the direct procurement of soles degenerates into a Probit model because this proportion happens to be either 0 or 1 at all the sample enterprises.

To test Hypothesis 3, enterprise size in terms of the logarithm of value added is regressed on $X_{i}$ :

$$
\ln V_{i t}=X_{i} \beta_{t}+u_{i t}
$$

where $\beta_{t}$ are coefficients which are allowed to vary over time, and $u_{i t}$ is an error term. We also ran growth regressions using the specification extensively used in the empirical literature on economic growth (e.g., Barro and Sala-i-Martin, 1992) and enterprise growth (e.g., Evans, 1987). It can be derived from equation (2) as follows. Let $\gamma$ be a convergence parameter to be estimated, and let $V_{i t-1}$ denote the lagged value added. By adding $\gamma \ln V_{i t-1}$ to the right-hand side of equation (2) and then subtracting its equivalent, $\gamma\left(X_{i} \beta_{t-1}+u_{i t-1}\right)$, we obtain

$$
\begin{aligned}
\ln V_{i t} & =X_{i} \beta_{t}+u_{i t}+\gamma \ln V_{i t-1}-\gamma\left(X_{i} \beta_{t-1}+u_{i t-1}\right) \\
& =\gamma \ln V_{i t-1}+X_{i}\left(\beta_{t}-\gamma \beta_{t-1}\right)+\left(u_{i t}-\gamma u_{i t-1}\right) .
\end{aligned}
$$

Subtracting $\ln V_{i t-1}$ from both sides of equation (3) and rearranging yield the familiar growth regression equation,

$$
\ln V_{i t}-\ln V_{i t-1}=\delta_{1} \ln V_{i t-1}+X_{i} \delta_{2}+w_{i t}
$$

where $\delta_{1}=\gamma-1, \delta_{2}=\beta_{t}-\gamma \beta_{t-1}$, and $w_{i t}=u_{i t}-\mu_{i t-1} . \quad$ In the literature on enterprise growth in Africa, McPherson (1996), Ramachandran and Shah (1999), Gunning and Mengistae 
(2001), and Mengistae (2001) commonly find that initial enterprise size, $\ln V_{i t-1}$, and the years of operation have negative effects on enterprise growth, $\ln V_{i t}-\ln V_{i t-1 .}{ }^{18}$ McPherson (1996), Ramachandran and Shah (1999), and Mengistae (2001, 2006) find positive effects of entrepreneur's schooling on enterprise growth.

\section{Estimation Results}

Table 4 presents the estimated functions that explain the determinants of shoe prices (see columns 1 to 3 ), the direct marketing proportion (column 4), and the direct procurement proportion (columns 5 and 6). The dummy for the second-generation entrepreneurs does not have a significant effect in any column. These results clearly indicate that the differences in product quality, marketing, and procurement behaviors between the first- and second-generation entrepreneurs, as indicated in Tables 4 and 5, came from the differences in their education levels or some other attributes.

\section{"INSERT Table 4 Here."}

In column 1 , the data in the three years under study are pooled, and the coefficients are assumed to be constant over time. This assumption is valid except for the coefficient of the university dummy, which became much smaller in 2004 than in 2000 and 2002, as shown in columns 2 and 3. The years of operation or the management experience always had a positive and highly significant effect on shoe prices. The effect of high education was weakened in 2004 by the fact that some of the highly educated entrepreneurs, including the owners of Ramsey and Peacock, increased the production of less expensive, military boots and casual shoes. These entrepreneurs had just begun focusing on the mechanized, mass production of standardized shoes for export markets. The coefficients of the year 
dummies in column 1 indicate that the average shoe price in 2000 and 2002 was a little lower than 90 percent of that in 2004.

Consistent with Hypothesis 1, column 4 of Table 4 shows that the university dummy and the years of operation of the current entrepreneur had positive and significant effects on the proportion of direct marketing. Although not reported in the table, we ran regressions separately for the three years and found that the coefficient of the university dummy increased from 0.54 in 2000 to 0.65 in 2002 and to 0.77 in 2004 . While these increases are not drastic, they lend further support to Hypothesis 2. An additional finding is that the years of prior experience in the shoe industry had a positive and significant effect on direct marketing. This result, together with the positive effect of the years of operation, suggests that the importance of direct marketing was strongly recognized by those who had long experience in shoemaking.

In columns 5 and 6 , the effects of the university dummy and the management experience on direct procurement proportions are all positive, consistent with Hypothesis 2. Those of the university dummy, however, are insignificant, and the effect of management experience on the direct procurement of leather is only marginally significant. Although not reported in the table, the OLS estimates of these effects are positive and significant. In the Tobit and Probit estimation, the statistical significance of these effects is low because only a very small number of the sample enterprises procured materials directly from producers. Indeed, only nine enterprises procured leather directly from tanneries, and nine enterprises procured soles directly from factories, of which six did both. Five of these six enterprises were owned by entrepreneurs with more than 10 years of management 
experience and four were owned by highly educated entrepreneurs. These enterprises were all eager to export their products to large foreign markets.

"INSERT Table 5 Here.”

Table 5 presents the estimated functions that explain the determinants of enterprise size and enterprise growth. While the coefficients in the size function are related to those in the growth function as shown in equations (3) and (4), the relationships among the estimated coefficients in Table 5 are not exact because the samples used in estimating the size function for $t-1$ and $t$ and the growth function for the period from $t-1$ to $t$ were a little different due to new entry and missing data. As in Table 4, the dummy for the second-generation entrepreneurs does not have a significant effect in any column in Table 5.

Consistent with Hypothesis 3, both the university dummy and the years of management experience had positive and highly significant effects on enterprise size, as shown in columns 1 to 4 . The negative and significant coefficients of year dummies in column 1 indicate that the average enterprise size in 2000 and 2002 was as small as $\operatorname{Exp}(-$ 0.53) or about 60 percent of that in 2004, because of the China shock. Columns 2 to 4 show that the magnitude of the effect of high education on enterprise size declined in 2002 and increased in 2004. The effect was weaker in 2002 because the large enterprises operated by highly educated entrepreneurs were most seriously hit by the China shock. For example, the sales revenue of Kangaroo, the largest private shoemaker in 2000, was reduced by half in two years. In accordance with the drastically weakened effect of the university dummy on enterprise size, its effect on growth was negative and significant in 
the period from 2000 to 2002, as shown in column 5. Such an impasse might drive the highly educated entrepreneurs to seriously consider the mass production of standardized but high-quality shoes for export.

In the recovery phase from 2002 to 2004, the university dummy had an increased effect on enterprise size and a positive and significant effect on growth, as shown in columns 4 and 6 , respectively. Its effect on enterprise size, however, did not regain the magnitude that it had had just before the China shock. There are two possible explanations for this. One is that Chinese shoes still occupy the women's shoe segment of the leather-shoe market, which used to be monopolized by some domestic enterprises with highly educated entrepreneurs. Another explanation is that multifaceted improvements led by highly educated entrepreneurs were just in the incipient stage. The size expansion of the innovative enterprises observed in the shoe industry in Addis Ababa was not yet as spectacular as Sonobe et al. (2004, 2006a, 2006b) have observed in several industries in East Asia, such as the electric appliance industry in Wenzhou and the motorcycle industry in Chongqing, where innovative enterprises achieved tremendous expansion in size. Qualitatively, however, the way in which the development process unfolds itself in Addis Ababa is similar to that in East Asia; i.e., quality improvement is accompanied by the adoption of new marketing and procurement strategies, improvements in production organization, and the emergence of large enterprises, and these multifaceted improvements are led by highly educated and experienced entrepreneurs.

While Mengistae (2001) finds that enterprises owned by Gurage entrepreneurs were larger and grew faster than other enterprises, our estimates of the Gurage effect on 
enterprise size are insignificant, as shown in columns 1 to 4 . Our result differs from Mengistae's probably because the overwhelming majority of our sample entrepreneurs are Gurage. The Gurage effect on enterprise growth is negative and highly significant in column 5 but it is positive and insignificant in column 6 . We are unable to explain these results. In column 5, the years of prior experience have a negative and significant effect, which suggests that those entrepreneurs experienced in trading performed better than former shoe workers when the industry suffered from the China shock.

The existing analyses of enterprise growth in Africa use enterprise data gathered from various industries and find that old incumbents hardly grow even though they are more likely to survive than new entrants. This is because industries in Africa as a whole are so static without technological and managerial progress that only newly established enterprises have the opportunity to grow by learning what incumbents already know. Unlike these results, our estimates of the growth effect of the years of operation are insignificant, as shown in columns 5 and 6, which suggests that old enterprises grow as rapidly as new ones. By contrast, this variable has positive and persistent effects on the enterprise size (see columns 1 to 4 ). Probably these estimation results reflect the fact that the industry under study is dynamically growing.

\section{Conclusions}

The leather-shoe industry in Ethiopia is producing shoes exportable to the markets in the developed countries. The industry took back the domestic market from Chinese shoes which had flooded the market in around 2001. Since then, the industry has been growing 
vigorously. These developments are good news to those who are interested in poverty reduction in Sub-Saharan Africa because Ethiopia is one of the poorest countries and the leather-shoe industry is one of the most labor-intensive industries which provide ample employment opportunities for the poor.

This paper has found that the industry's growth has been driven not only by the entry of new enterprises but also by the growth of leading enterprises and followers, as in East Asia. Moreover, the paper has presented supportive evidence for the hypothesis that the highly educated entrepreneurs introduce new ideas on product design, production methods, labor management, marketing, and procurement because they face fierce competition from a swarm of micro enterprises, who can enter the market with little investments. Qualitatively, the development process of the leather-shoe industry in Ethiopia bears similarities to the process of the cluster-based industrial development observed in East Asia.

The will of the educated entrepreneurs to carry out multifaceted innovations or improvements seems to have been increasing. However, they have not yet succeeded in innovative improvements in management, marketing, and technology, which have occurred in East Asia. To support the further development of the shoe cluster in Addis Ababa, it is essential for the government, foreign aid agencies, and NGOs to assist in training the entrepreneurs so that they can upgrade management, marketing, and technology much sooner and more thoroughly than otherwise. The Ethiopian government established the Leather and Leather Products Technology Institute in order to support the formation of skilled labor force and the dissemination of advanced technologies. This is a good move but should be supplemented by the provision of training of marketing and management 
skills.

\section{Notes}

1 See Bigsten and Söderbom (2006) for a recent review of the literature on the industrial development in sub-Saharan Africa.

2 Leather shoes are footwear with outer soles of rubber, plastics, leather or composition leather and uppers of leather, i.e., footwear classified as HS Code 6403.

3 Armenians also established a modern leather tannery in the 1920s in Addis Ababa.

4 Porter (1998, p.18) defines industrial clusters as "geographic concentrations of interconnected companies and institutions in a particular field" and similarly Schmitz and Nadvi (1999) define them as "sectoral and spatial concentration of firms."

5 Nadvi (1999) and Schmitz (1995) argue that improvements in quality and efficiency are associated with improvements in the long-term supplier-manufacturer relations.

6 Note that the innovation here does not refer to the development of truly new products or new production methods using the most advanced scientific discoveries or engineering inventions. Viewed from the developed countries, innovations in developing countries are not far from the imitation of innovations in the remote past.

7 Tikur Abbay employed 500 workers in 2000 and 280 in 2004. Anbessa employed 750 workers in 2000 and 660 in 2004. While Anbessa had larger labor force than Tikur Abaay, the value added of the latter was nearly four times as large as that of the former.

8 The average price is the US dollar value of imports or exports divided by the number of 
pairs imported or exported. Throughout the paper, nominal values in Ethiopian Birr are converted into US dollar values by using the exchange rate data taken from IMF (2007).

9 We cannot find the wage earnings in the leather shoe industry in China, which accounts for about $40 \%$ of products of the leather industry.

10 Value added here is defined as sales revenue minus the cost of intermediate inputs such as leather, soles, and accessories, as the cost of energy and water was negligible.

11 Some of the second-generation entrepreneurs were born outside Addis Ababa because their fathers were initially farmers and then became migrant workers employed in the leather-shoe industry in Addis Ababa.

12 Lika (1997) describes the operation of leather-shoe enterprises in Addis Ababa and the working conditions of their workers based on survey data of 82 enterprises.

13 According to Table 3 of Gunning and Mengistae (2001), enterprises in the leather products industry in Ethiopia grew by 28 percent over the five year period from 1989 to 1993, whereas other industries recorded negative growth.

14 We compare prices of men's shoes rather than those of ladies' and children's shoes because most sample enterprises produce men's shoes.

15 An appropriate price index in Ethiopia for leather shoes to be used to obtain real prices is unavailable. To compare shoe prices between 2000 and 2004, nominal prices in Ethiopian Birr were converted into US dollar equivalents using the average exchange rate in each year. The data on exchange rate were taken from IMF (2007).

16 Consistent with these observations, Stokke (2008) exemplifies the increasing importance of education in technology adoption. 
17 The corresponding growth rates for the SOEs were -20.5 percent in the first period and -7.2 percent in the second period.

18 Mengistae (2006) corrects for the attrition bias arising from the use of the sample consisting only of surviving enterprises. 


\section{References}

Akoten, John E., Yasuyuki Sawada and Keijiro Otsuka, "The Determinants of Credit Access and its Impacts on Micro and Small Enterprises: The Case of Garment Producers in Kenya,” Economic Development and Cultural Change 54 (2006):927-44.

Barro, Robert and Xavier Sala-i-Martin, “Convergence," Journal of Political Economy 100 (1992):223-51.

Bazan, Luiza and Lizbeth Navas-Aleman, "The Underground Revolution in the Sinos Valley: A Comparison of Upgrading in Global and National Value Chains," in Hubert Schmitz (ed.), Local Enterprises in the Global Economy, Cheltenham, UK: Edward Elgar, 2004.

Bigsten, Arne and Måns Söderbom, "What Have We Learned from a Decade of Manufacturing Enterprise Surveys in Africa?" World Bank Research Observer 21 (2006):241-65.

China, National Bureau of Statistics, China Labor Statistical Yearbook, Beijing: China Statistics Press (various issues).

China, National Bureau of Statistics, China Statistical Yearbook, Beijing: China Statistics Press (2005).

Collier, Paul and Jan Willem Gunning, "Explaining African Economic Performance," Journal of Economic Literature 37 (1999):64-111.

Evans, David S., “Tests of Alternative Theories of Firm Growth,” Journal of Political Economy 95 (1987):657-74.

Fafchamps, Marcel, Market institutions and Sub-Saharan Africa: Theory and evidence, 
Cambridge, MA: MIT Press, 2004.

Gunning, Jan Willem and Taye Mengistae, "Determinants of African Manufacturing Investment: The Microeconomic Evidence," Journal of African Economies 10 (2001): 48-80.

International Monetary Fund, World Economic Outlook Database, April 2007 Edition. http://www.imf.org/external/pubs/ft/weo/2007/01/data/index.htm

Knorringa, Peter, “Agra: An Old Cluster Facing the New Competition,” World Development 27 (1999):1587-604.

Lika, T., "Employment and Income in the Urban Informal Sector: A Case Study of Informal Leather Shoe Making Enterprises in Wereda 5, Addis Ababa,” Unpublished M.A. Thesis, Addis Ababa University, Addis Ababa, 1997.

Marshall, Alfred, Principles of Economics, 8th Ed., London: Macmillan \& Co. Ltd. 1920.

McCormick, Dorothy, “African Enterprise Clusters and Industrialization: Theory and Reality," World Development 27 (1999):1531-51.

McPherson, Michael, "Growth of Micro and Small Enterprises in Southern Africa," Journal of Development Economics 48 (1996):253-77.

Mengistae, Taye, “Indigenous Ethnicity and Entrepreneurial Success in Africa: Some Evidence from Ethiopia,” World Bank Policy Research Working Paper 2534, 2001.

—_ 'Competition and Entrepreneurs' Human Capital in Small Business Longevity and Growth," Journal of Development Studies 42 (2006):812-36.

Nadvi, Khalid, “Collective Efficiency and Collective Failure: The Response of the Sialkot Surgical Instrument Cluster to Global Quality Pressures,” World Development 27 
(1999): 1605-26.

Piore, Michael J. and Charles F. Sabel, The Second Industrial Divide: Possibilities for Prosperity, New York: Basic Books, 1984.

Porter, Michael E., "Clusters and the New Economics of Competition," Harvard Business Review November-December (1998):77-90.

Rabelloti, Roberta, “Is there an 'Industrial District Model?’ Footwear District in Italy and Mexico Compared," World Development 23 (1995):29-41.

Ramachandran, Vijaya and Manju Kedia Shar, "Minority Entrepreneurs and Firm Performance in Sub-Saharan Africa," Journal of Development Studies 36 (1999):71-87.

Schmitz, Hubert, "Small Shoemakers and Fordist Giants: Tale of a Supercluster,” World Development 23 (1995):9-28.

Schmitz, Hubert and Khalid Nadvi, "Clustering and Industrialization," World Development 27 (1999):1503-14.

Sonobe, Tetsushi, Dinghuan Hu and Keijiro Otsuka, "Process of Cluster Formation in China: A Case Study of a Garment Town,” Journal of Development Studies 39 (2002):118-39.

— , "From Inferior to Superior Products: An Inquiry into the Wenzhou Model of Industrial Development in China," Journal of Comparative Economics 32 (2004):542-63.

— , "Industrial Development in the Inland Region of China: A Case Study of the Motorcycle Industry," Journal of Comparative Economics 34 (2006):818-38. 
Sonobe, Tetsushi and Keijiro Otsuka, Cluster-Based Industrial Development: An East Asian Model, Basingstoke: Palgrave Macmillan, 2006a.

_ , "The Division of Labor and the Formation of Industrial Clusters in Taiwan," Review of Development Economics 10 (2006b): 71-86.

Stokke, Hildegunn E., "Productivity Growth and Organizational Learning," Review of Development Economics 12 (2008):764-778. 
Table 1. Number of Sample Enterprises, their Average Sizes, and Owners' Observable Human Capital in 2004 by Owner Type

\begin{tabular}{|c|c|c|c|c|}
\hline & \multicolumn{3}{|c|}{ Years of operation } & \multirow[b]{2}{*}{ All } \\
\hline & 2 to 4 years & 5 to 9 years & 10 years + & \\
\hline & (1) & (2) & (3) & (4) \\
\hline \multicolumn{5}{|c|}{$\begin{array}{l}\text { Owner without a parent in the shoe } \\
\text { business }\end{array}$} \\
\hline Number of observations & 43 & 23 & 6 & 72 \\
\hline Average number of workers & 5.0 & 6.3 & 7.9 & 5.7 \\
\hline $\begin{array}{l}\text { Value added (US\$1,000) } \\
\text { (Annual growth rate, 2002-04, \%) }\end{array}$ & $\begin{array}{c}7.1 \\
(27.6)\end{array}$ & $\begin{array}{c}9.6 \\
(13.3)\end{array}$ & $\begin{array}{l}17.0 \\
(24.0)\end{array}$ & $\begin{array}{c}8.7 \\
(23.1)\end{array}$ \\
\hline$\%$ entered university & 2.3 & 0 & 0 & 1.4 \\
\hline Years of prior experience & 10.2 & 10.7 & 10.8 & 10.4 \\
\hline \multicolumn{5}{|l|}{ Owner with a parent in the shoe business } \\
\hline Number of observations & 4 & 9 & 5 & 18 \\
\hline Average number of workers & 5.8 & 20.6 & 58.8 & 27.9 \\
\hline $\begin{array}{l}\text { Value added (US\$1,000) } \\
\text { (Annual growth rate, 2002-04, \%) }\end{array}$ & $\begin{array}{c}5.9 \\
(44.0)\end{array}$ & $\begin{array}{c}84.8 \\
(44.6)\end{array}$ & $\begin{array}{l}107.7 \\
(9.8)\end{array}$ & $\begin{array}{c}73.6 \\
(34.3)\end{array}$ \\
\hline$\%$ entered university & 25.0 & 44.4 & 60.0 & 44.4 \\
\hline Years of prior experience & 7.1 & 4.4 & 4.5 & 5.0 \\
\hline
\end{tabular}


Table 2. Comparison of Nominal Annual Wage Earnings in the Urban Leather Industry in China and in the Leather Shoe Industry in Ethiopia (US\$ per year)

\begin{tabular}{lccc}
\hline & $\begin{array}{c}\text { China } \\
(1)\end{array}$ & $\begin{array}{c}\text { Ethiopia } \\
(2)\end{array}$ & $\begin{array}{c}\text { Ratio } \\
(2) /(1)\end{array}$ \\
\hline 2000 & 967 & 406 & 0.42 \\
2001 & 992 & -- & -- \\
2002 & 1,100 & 412 & 0.37 \\
2003 & 1,164 & -- & -- \\
2004 & 1,296 & 517 & 0.4 \\
2005 & 1,526 & -- & --
\end{tabular}

a. The urban leather industry in China refers to the manufacturing industries of leather, fur, feather, and their products in urban areas. The wage data of the leather-shoe industry in Ethiopia is based on our own data. Wage earnings in local currencies are converted to the U.S. dollars by using the official exchange rates.

Sources: China Labor Statistical Yearbook (various issues) for wage data and China Statistical Yearbook (2005) for the exchange rate between US dollars and Chinese Yuan, and the International Monetary Fund (2005) for the exchange rate between US dollars and Ethiopian birr. 
Table 3. Price of Men's Shoes and Marketing Channels of Products and Materials in 2004 by Owner Type

\begin{tabular}{|c|c|c|c|c|}
\hline & \multicolumn{3}{|c|}{ Years of operation } & \multirow[b]{2}{*}{ All } \\
\hline & 2 to 4 years & 5 to 9 years & 10 years + & \\
\hline & $(1)$ & $(2)$ & $(3)$ & (4) \\
\hline \multicolumn{5}{|c|}{$\begin{array}{l}\text { Owner without a parent in the } \\
\text { shoe business }\end{array}$} \\
\hline Men's shoe price (USD) & 6.14 & 6.90 & 8.03 & 6.54 \\
\hline Direct marketing (\%) & 0 & 0.7 & 15.8 & 2.8 \\
\hline $\begin{array}{l}\text { Leather directly from } \\
\text { tanneries }^{\text {a }}\end{array}$ & 0 & 3.0 & 13.3 & 2.1 \\
\hline Soles imported $(\%)^{\mathrm{b}}$ & 0 & 0 & 10.0 & 0.8 \\
\hline $\begin{array}{l}\text { Soles directly from } \\
\text { factories }(\%)^{\mathrm{c}}\end{array}$ & 0 & 0 & 23.3 & 1.9 \\
\hline \multicolumn{5}{|c|}{$\begin{array}{l}\text { Owner with a parent in the } \\
\text { shoe business }\end{array}$} \\
\hline Men's shoe price (USD) & 6.66 & 9.28 & 12.52 & 9.60 \\
\hline Direct marketing $(\%)$ & 0 & 4.4 & 76.0 & 23.3 \\
\hline $\begin{array}{l}\text { Leather directly from } \\
\text { tanneries }{ }^{\text {a }}\end{array}$ & 0 & 11.1 & 100 & 22.2 \\
\hline Soles imported $(\%)^{\mathrm{b}}$ & 0 & 0 & 38.0 & 10.6 \\
\hline $\begin{array}{l}\text { Soles directly from } \\
\text { factories }(\%)^{\mathrm{c}}\end{array}$ & 0 & 44.4 & 22.0 & 28.3 \\
\hline
\end{tabular}

a. This row shows the percentage of the value of leather bought directly from leather tanneries. The other source of leather is the wholesalers of shoe materials, whose shops are located in Merkato.

b. This is the percentage of the value of shoe soles imported.

c. This is the percentage of the value of shoe soles bought directly from sole factories, including own sole factories. Other soles are procured from shoe material wholesalers, whose shops are located in Merkato. 
Table 4. Estimated Regression Models for Product Pricing, Marketing, and Input Procurement $^{\text {a }}$

\begin{tabular}{|c|c|c|c|c|c|c|}
\hline \multirow{5}{*}{$\begin{array}{l}\text { Dependent } \\
\text { variable } \\
\text { Sample year } \\
\text { Estimator }\end{array}$} & \multicolumn{3}{|c|}{$\ln ($ price $)$} & \multirow{3}{*}{$\begin{array}{c}\begin{array}{c}\text { Direct } \\
\text { marketing }\end{array} \\
00,02,04\end{array}$} & \multicolumn{2}{|c|}{ Direct procurement } \\
\hline & & & & & \multirow{2}{*}{$\begin{array}{c}\text { Leather } \\
04\end{array}$} & \multirow{2}{*}{$\begin{array}{c}\text { Soles } \\
04\end{array}$} \\
\hline & $00,02,04$ & 00,02 & 04 & & & \\
\hline & \multicolumn{3}{|c|}{ OLS } & \multicolumn{2}{|c|}{ Tobit } & Probit \\
\hline & (1) & (2) & (3) & (4) & (5) & (6) \\
\hline Second generation & $\begin{array}{l}0.085 \\
(1.18)\end{array}$ & $\begin{array}{l}-0.010 \\
(-0.10)\end{array}$ & $\begin{array}{l}0.166 \\
(1.65)\end{array}$ & $\begin{array}{l}0.108 \\
(0.49)\end{array}$ & $\begin{array}{l}0.864 \\
(0.52)\end{array}$ & $\begin{array}{l}0.918 \\
(1.52)\end{array}$ \\
\hline University & $\begin{array}{l}0.211^{*} \\
(2.25)\end{array}$ & $\begin{array}{c}0.348 * * \\
(2.58)\end{array}$ & $\begin{array}{l}0.103 \\
(0.80)\end{array}$ & $\begin{array}{c}0.652 * * \\
(2.54)\end{array}$ & $\begin{array}{l}2.327 \\
(1.14)\end{array}$ & $\begin{array}{l}0.467 \\
(0.60)\end{array}$ \\
\hline Years of operation & $\begin{array}{c}0.029 * * \\
(6.05)\end{array}$ & $\begin{array}{c}0.029 * * \\
(4.49)\end{array}$ & $\begin{array}{c}0.028 * * \\
(4.00)\end{array}$ & $\begin{array}{c}0.083 * * \\
(5.78)\end{array}$ & $\begin{array}{c}0.367 * \\
(1.79)\end{array}$ & $\begin{array}{c}0.079 * \\
(2.10)\end{array}$ \\
\hline $\begin{array}{c}\text { Years of prior } \\
\text { experience }\end{array}$ & $\begin{array}{l}-0.004 \\
(-1.12)\end{array}$ & $\begin{array}{l}-0.001 \\
(-0.31)\end{array}$ & $\begin{array}{l}-0.006 \\
(-1.18)\end{array}$ & $\begin{array}{l}0.023^{*} \\
(2.27)\end{array}$ & $\begin{array}{l}0.043 \\
(0.67)\end{array}$ & $\begin{array}{l}-0.103 \\
(-1.52)\end{array}$ \\
\hline Gurage & $\begin{array}{l}-0.052 \\
(-0.76)\end{array}$ & $\begin{array}{l}-0.027 \\
(-0.26)\end{array}$ & $\begin{array}{l}-0.048 \\
(-0.52)\end{array}$ & $\begin{array}{l}-0.082 \\
(-0.42)\end{array}$ & $\begin{array}{l}-1.232 \\
(-0.77)\end{array}$ & $\begin{array}{l}-0.145 \\
(-0.18)\end{array}$ \\
\hline Year 2000 & $\begin{array}{l}-0.119 * \\
(-1.92)\end{array}$ & $\begin{array}{l}0.003 \\
(0.05)\end{array}$ & & $\begin{array}{l}0.017 \\
(0.11)\end{array}$ & & \\
\hline Year 2002 & $\begin{array}{c}-0.135 * * \\
(-2.85)\end{array}$ & & & $\begin{array}{l}-0.086 \\
(-0.57)\end{array}$ & & \\
\hline Intercept & $\begin{array}{l}1.782 * * \\
(23.10)\end{array}$ & $\begin{array}{c}1.611 * * \\
(14.65)\end{array}$ & $\begin{array}{c}1.799 * * \\
(17.77)\end{array}$ & $\begin{array}{c}-1.518 * * \\
(-4.20)\end{array}$ & $\begin{array}{l}5.415 \\
(1.62)\end{array}$ & $\begin{array}{l}-1.575 \\
(-1.79)\end{array}$ \\
\hline Sample size & 204 & 109 & 89 & 216 & 90 & 90 \\
\hline R-squared & 0.34 & 0.34 & 0.34 & & & \\
\hline $\begin{array}{l}\text { No. of left- and } \\
\text { right-censored obs. }\end{array}$ & & & & $\begin{array}{l}\text { Left: } 188 \\
\text { Right: } 4\end{array}$ & $\begin{array}{l}\text { Left: } 81 \\
\text { Right: } 6\end{array}$ & \\
\hline
\end{tabular}

a. Numbers in parentheses are $t$-statistics. $*$ and $* *$ indicate 5 percent and 1 percent levels of statistical significance, respectively. One-sided alternative hypotheses are used in the $t$-tests except for the intercept. 
Table 5. Estimated Regression Models for Enterprise Size and Growth ${ }^{\text {a }}$

\begin{tabular}{|c|c|c|c|c|c|c|}
\hline \multirow{3}{*}{$\begin{array}{r}\text { Dependent variable } \\
\text { Sample year } \\
\text { and period }\end{array}$} & \multicolumn{4}{|c|}{$\ln V_{t}$} & \multicolumn{2}{|c|}{$\ln V_{t}-\ln V_{t-1}$} \\
\hline & $\begin{array}{c}00,02 \\
04\end{array}$ & 00 & 02 & 04 & $00-02$ & $02-04$ \\
\hline & (1) & (2) & (3) & (4) & $(5)$ & (6) \\
\hline $\ln V_{t-1}$ & & & & & $\begin{array}{l}0.041 \\
(0.34)\end{array}$ & $\begin{array}{c}-0.143 * * \\
(-2.48)\end{array}$ \\
\hline Second generation & $\begin{array}{l}-0.011 \\
(-0.04)\end{array}$ & $\begin{array}{l}-0.191 \\
(-0.32)\end{array}$ & $\begin{array}{l}-0.081 \\
(-0.18)\end{array}$ & $\begin{array}{l}0.135 \\
(0.31)\end{array}$ & $\begin{array}{l}0.266 \\
(0.76)\end{array}$ & $\begin{array}{l}0.301 \\
(1.33)\end{array}$ \\
\hline University & $\begin{array}{c}1.618 * * \\
(4.71)\end{array}$ & $\begin{array}{c}2.415 * * \\
(3.25)\end{array}$ & $\begin{array}{l}1.157 * \\
(2.07)\end{array}$ & $\begin{array}{c}1.547 * * \\
(2.73)\end{array}$ & $\begin{array}{c}-1.525^{*} \\
(-2.42)\end{array}$ & $\begin{array}{c}0.529 * \\
(2.03)\end{array}$ \\
\hline Years of operation & $\begin{array}{c}0.115^{* *} \\
(6.16)\end{array}$ & $\begin{array}{c}0.130 * * \\
(3.22)\end{array}$ & $\begin{array}{c}0.123 * * \\
(4.09)\end{array}$ & $\begin{array}{c}0.101 * * \\
(3.27)\end{array}$ & $\begin{array}{l}-0.042 \\
(-1.66)\end{array}$ & $\begin{array}{l}-0.011 \\
(-0.79)\end{array}$ \\
\hline $\begin{array}{c}\text { Years of prior } \\
\text { experience }\end{array}$ & $\begin{array}{l}-0.018 \\
(-1.25)\end{array}$ & $\begin{array}{l}-0.014 \\
(-0.40)\end{array}$ & $\begin{array}{l}-0.030 \\
(-1.31)\end{array}$ & $\begin{array}{l}-0.009 \\
(-0.37)\end{array}$ & $\begin{array}{c}-0.042 * * \\
(-3.19)\end{array}$ & $\begin{array}{l}0.017 \\
(1.21)\end{array}$ \\
\hline Gurage & $\begin{array}{l}-0.024 \\
(-0.09)\end{array}$ & $\begin{array}{l}-0.033 \\
(-0.05)\end{array}$ & $\begin{array}{l}-0.167 \\
(-0.41)\end{array}$ & $\begin{array}{l}0.111 \\
(0.27)\end{array}$ & $\begin{array}{c}-0.846 * * \\
(-3.34)\end{array}$ & $\begin{array}{l}0.271 \\
(1.54)\end{array}$ \\
\hline Year 2000 & $\begin{array}{c}-0.543 * \\
(-2.27)\end{array}$ & & & & & \\
\hline Year 2002 & $\begin{array}{c}-0.526 * * \\
(-2.86)\end{array}$ & & & & & \\
\hline Intercept & $\begin{array}{c}8.055 * * \\
(26.79)\end{array}$ & $\begin{array}{c}7.266 * * \\
(8.80)\end{array}$ & $\begin{array}{l}7.778 * * \\
(17.54)\end{array}$ & $\begin{array}{l}7.911 * * \\
(17.85)\end{array}$ & $\begin{array}{l}1.556^{*} \\
(2.32)\end{array}$ & $\begin{array}{l}1.227 * \\
(2.52)\end{array}$ \\
\hline Sample size & 214 & 39 & 86 & 89 & 36 & 85 \\
\hline R-squared & 0.37 & 0.53 & 0.33 & 0.30 & 0.41 & 0.12 \\
\hline
\end{tabular}

a. Numbers in parentheses are $t$-statistics. For columns 5 and $6, t$-statistics are calculated based on the White standard errors robust to heteroscedasticity. $*$ and $* *$ indicate 5 percent and 1 percent levels of statistical significance, respectively. One-sided alternative hypotheses are used in the t-tests except for the intercept. 


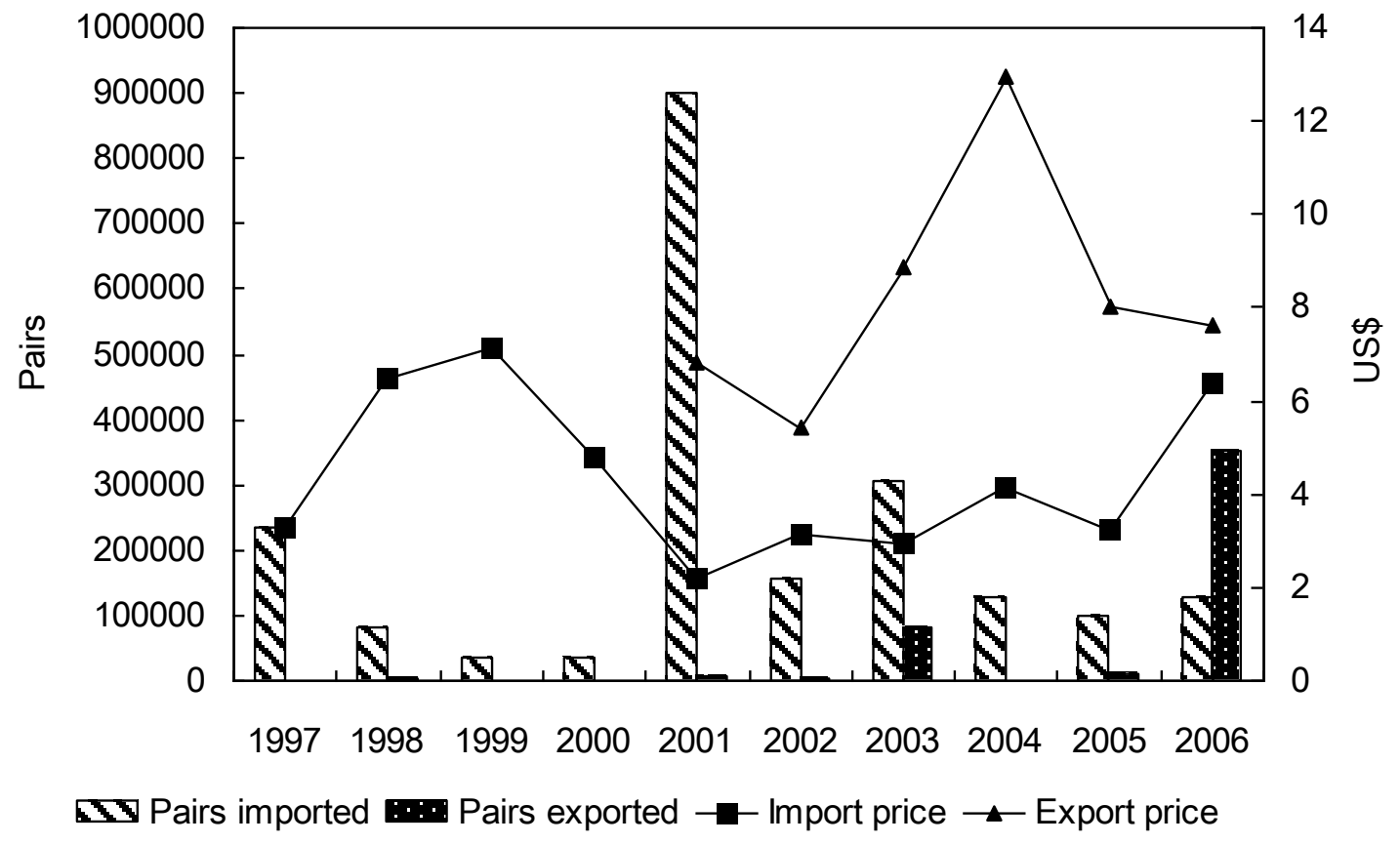

Data source: Ethiopian Foreign Trade Statistics (various years).

Figure 1. Number of Pairs of Imported and Exported Leather Shoes and their Average Prices, $1997-2006$ 